\title{
Synthesis and characterization of belite calcium sulfoaluminate cements produced by oxyfuel combustion residues
}

\author{
A. Telesca*1, M. Marroccoli ${ }^{2}$, N. Ibris ${ }^{3}$, \\ T. R., Naik ${ }^{4}$, C. Lupiáñez ${ }^{5}$, L. I. Díez ${ }^{6}$ L. M. Romeo ${ }^{7}$ and F. Montagnaro ${ }^{8}$ \\ ${ }^{1-3}$ School of Engineering, Università degli Studi della Basilicata, ITALY. \\ (E-mail: antonio.telesca@unibas.it, milena.marroccoli@unibas.it, neluta.ibris@unibas.it) \\ ${ }^{4}$ Department of Civil Engineering and Mechanics, University of Wisconsin, USA \\ (E-mail: tarun@uwm.edu) \\ ${ }^{5-7}$ Mechanical Engineering Department, Universidad de Zaragoza, SPAIN. \\ (E-mail: carlos.lupianez@unizar.es, luisig@unizar.es, luismi@unizar.es) \\ ${ }^{4}$ Department of Chemical Sciences, Università degli Studi di Napoli Federico II, ITALY. \\ (E-mail: fabio.montagnaro@unina.it)
}

\begin{abstract}
In this work, the possibility of reusing ashes issued by an oxyfuel combustion process (OC) as a source of material in the production of belite calcium sulfoaluminate BCSA cements has been investigated. OF process is one of the most promising combustion technologies for $\mathrm{CO}_{2}$ reduction from power plants. Combustion tests were carried out in an oxyfuel bubbling fluidized bed pilot plant. Four BCSA clinker-generating raw mixes were heated in a laboratory electric oven in the temperatures range $1150^{\circ}$ $1350^{\circ} \mathrm{C}$ : one included only natural materials (limestone, clay, bauxite and gypsum), the others contained OC ashes as total substitute for clay.

$\mathrm{X}$-ray diffraction (XRD) analysis on the burning products showed high conversion of reactants toward the main BCSA clinker components $\left(\mathrm{C}_{2} \mathrm{~S}\right.$ and $\left.\mathrm{C}_{4} \mathrm{~A}_{3} \$\right)$, especially at $1200^{\circ}$ or $1250^{\circ} \mathrm{C}$. Moreover, physical-mechanical tests associated with XRD and differential thermal-thermogravimetric analyses accomplished on all the cements (obtained by adding natural gypsum to the clinkers produced at the best synthesis temperatures) generally displayed a similar hydration behaviour.
\end{abstract}

Keywords: Oxyfuel combustion residues, clinker, belite calcium sulfoaluminate.

\section{INTRODUCTION}

The rapid growth of World population, the energy demand increase, the global warming (GW) have pushed governments and international authorities to set on the path towards sustainable development. There is no doubt that GW represents the most significant challenge to achieving sustainable development; this phenomenon is caused by the emission and accumulation in the atmosphere of greenhouse gases

\footnotetext{
*Corresponding author. T: +39 0971 205225. E-mail: antonio.telesca@ unibas.it.
} 
(GHGs) which are mainly released by the burning of fossil fuels, land clearing, agriculture-related and other human activities [Benhelal et al., 2013; De Richter et al., 2016; Szulejko et al., 2017; Telesca et al., 2017]. Carbon dioxide is blamed to be the main responsible for $\mathrm{GW}$; therefore, searching for promising approaches to mitigate $\mathrm{CO}_{2}$ emissions represents the priority of studies aimed at alleviating the threat of climate change. In this regard, the carbon capture and storage (CCS) technology has the potential to almost completely eliminate $\mathrm{CO}_{2}$ [Boot-Handford et al., 2014; Leung et al., 2014; Telesca et al., 2014a; Telesca et al., 2017]. CCS indicates a group of technologies developed to obtain $\mathrm{CO}_{2}$-rich flue gases ready to be stored by injection into geological strata with specific features. Among the different CCS processes (e.g., chemical absorption, chemical and calcium looping), oxyfuel combustion (OC) is of great interest due to its conceptual simplicity [Diez et al., 2015]. In OC a blend of nearly pure oxygen and part of exhaust gas (employed as $\mathrm{O}_{2}$ diluent for safety reasons), is used for combustion, thus lowering both $\mathrm{N}_{2}$ and $\mathrm{NO}_{\mathrm{X}}$ contents in the exhaust gas [Buhre et al., 2005; Lupiáñez et al., 2013a; Lupiáñez et al., 2014]. In absence of the most relevant diluent for $\mathrm{CO}_{2}$ and after further treatments, it is possible to obtain streams $>90 \% \mathrm{CO}_{2}$-rich. The $\mathrm{CO}_{2}$-rich stream is thus ready for final processing and geological storage.

Cement production is one of the most large-scale raw materials consuming as well as energy-intensive manufacturing processes and represents one of the major industrial sectors giving rise to $\mathrm{CO}_{2}$ emission. In fact, the World's annual cement production currently accounts for about 4.7 billion tons [Activity report 2016, 2017] and its contribution to the global anthropogenic $\mathrm{CO}_{2}$ emission is estimated as high as $7 \%$ (about 26\% of the industrial $\mathrm{CO}_{2}$ emission) [Tregambi et al., 2018]. It is therefore widely accepted the need to increase the sustainability of cement mainly oriented at mitigating the $\mathrm{CO}_{2}$ impact.

Portland cement (PC) is the most widely used binder all over the World; it is obtained by intergrinding PC clinker (PCC) with a few percent of calcium sulfates (mostly gypsum). For each $\mathrm{kg}$ of PCC produced, about $0.87 \mathrm{~kg}$ of $\mathrm{CO}_{2}$ are released [Barcelo et al., 2014]; carbon dioxide comes from both limestone thermal decomposition (about $60 \%$ of the total $\mathrm{CO}_{2}$ emission) and fuel combustion. Therefore, one approach to lower $\mathrm{CO}_{2}$ emissions is related to the limestone reduction in the clinker-generating raw meal [Telesca et al., 2016]. In this regard, belite rich-cements are considered environmentally friendly binders inasmuch as they can allow a $\mathrm{CO}_{2}$ reduction as much as 10\% [Pimraksa et al., 2009; Cuberos et al., 2010]; moreover, the presence of calcium sulfoaluminate $\left(\mathrm{C}_{4} \mathrm{~A}_{3} \$\right)$ in the cement clinker can both compensate the lower reactivity of belite (relative to alite) and further reduce the limestone requirement in the raw feed [Quillin, 2001]. Belite calcium sulfoaluminate (BCSA) cements generally display physical and mechanical properties comparable to OPC [Selçuk et al., 2010]; in fact, their technical behaviour mostly depends on the ability of $\mathrm{C}_{4} \mathrm{~A}_{3} \$$ and $\mathrm{C}_{2} \mathrm{~S}$, to respectively generate, upon hydration, $\mathrm{C}_{6} \mathrm{~A} \$_{3} \mathrm{H}_{32}$, ettringite (at early ages) and $\mathrm{CSH}$ (at medium and longer ages). Moreover, BCSA cements are interesting hydraulic binders from the environmental point of view inasmuch as their manufacturing process, compared to that of OPC, displays a pronounced environmentally friendly character mainly associated to (a) the relatively low synthesis temperature, (b) the decreased specific fuel consumption [Marroccoli et al., 2010a], (c) the easier 
grindability and (d) the greater usability of industrial wastes and by-products whose utilization is generally complicated [Marroccoli et al., 2009; Marroccoli et al., 2010b; Ma et al., 2014; Shen and Qian, 2015]. BCSA cements are generally produced by burning a raw mix composed by limestone (L), bauxite (B), clay (C) and gypsum $(\mathrm{G})$ at temperatures ranging from $1250^{\circ}-1350^{\circ} \mathrm{C}$ [Xue et al., 2016].

In this paper, residues generated during an OC process, carried out in a pilot-scale fluidized bed (FB) reactor, were tested as substitutes for clay in the BCSA clinkergenerating raw mix.

Four mixtures were heated in a laboratory electric oven in the temperatures range $1150^{\circ}-1350^{\circ} \mathrm{C}$ : one included only natural materials (taken as a reference term), the others contained OC residues in a measure comprised between 24.5 and $56.0 \%$ by mass. The conversion of reactants towards $\mathrm{C}_{2} \mathrm{~S}$ and $\mathrm{C}_{4} \mathrm{~A}_{3} \$$ was investigated by means of X-ray diffraction (XRD) analysis. XRD and differential thermal-thermogravimetric (DT-TG) analyses together with physical and mechanical tests were employed as main characterization techniques to carry out the investigation.

\section{EXPERIMENTAL}

\section{Materials and Oxyfuel Pilot Plant}

The natural materials ( $\mathrm{L}, \mathrm{C}, \mathrm{B}$ and $\mathrm{G}$ ) used in this investigation were taken from quarries located in Italy. The OC ashes came from a $95 \mathrm{~kW}_{\text {th }}$ pilot-scale bubbling oxyfuel fluidized bed $(\mathrm{FB})$ reactor $(2.5 \mathrm{~m}$ high with an inner diameter of $21 \mathrm{~cm})$; it is schematically reported in Figure 1 and described elsewhere [Lupiáñez et al., 2013b].

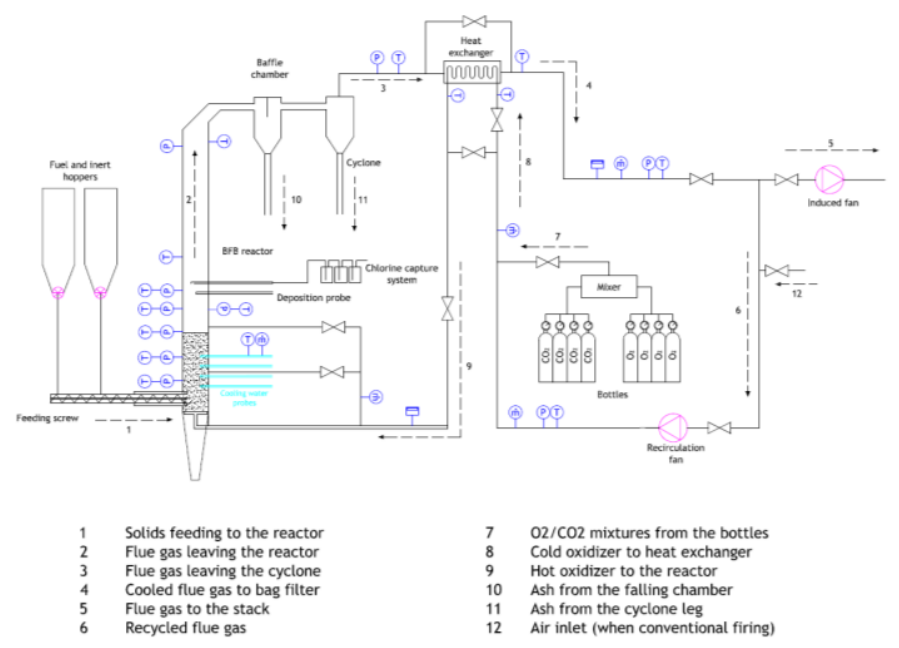

Figure 1. Oxyfuel fluidized bed pilot plant.

The FB reactor $(\mathrm{R})$, cooled by means of a water jacket placed at its bottom and four water-cooled probes uniformly distributed, was charged with a bed inventory of $5 \mathrm{~kg}$ silica sand, fluidized at $0.8 \mathrm{~ms}^{-1}$ (with a $65 \% \mathrm{CO}_{2}-35 \% \mathrm{O}_{2}$ mixture) and heated up to $850^{\circ} \mathrm{C}$ or $925^{\circ} \mathrm{C}$; it was equipped with two different devices for the removal of fly ash (baffle chamber, BC, and cyclone, CY, in the order) from the flue gas stream.

A blend of lignite and biomass corn stover fed the apparatus in a 70:30 energy ratio; 
moreover, to capture the $\mathrm{SO}_{2}$ generated during the combustion through the in situ desulfurization (calcium, $\mathrm{Ca}$ (in the sorbent): sulfur, $\mathrm{S}$ (in the fuel)), two different limestones (A and B) were alternatively injected into FBR.

Three different tests were performed: their operating conditions, for the sake of clarity, are summarized in Table 1. During each test, three kind of combustion residues were collected: a bottom ash (BA), extracted from the bottom of FBR, and two fly ashes (BCFA, CYFA) withdrawn along the flue gas treatment line.

Table 1. Operating conditions of the tests carried out in the in the FBR.

\begin{tabular}{|c|c|c|c|c|}
\hline Test no. & Fuel & Limestone & Ca:S & FBR Temperature, ${ }^{\circ} \mathrm{C}$ \\
\hline 1 & Lignite+Corn stover & A & 2 & 925 \\
\hline 2 & “ & A & 6 & 850 \\
\hline 3 & " & B & 6 & 925 \\
\hline
\end{tabular}

The residues of each test were then mixed to prepare three blends (B1, B2 and B3), proportioned consistent with the corresponding amount generated during the experimental activity (40\%BA-50\%BCFA-10\%CYFA).

The chemical composition (in terms of major oxides) of the raw materials, determined by X-ray fluorescence technique (wavelength dispersive BRUKER Explorer S4 apparatus), is shown in Table 2.

Table 2. Chemical analysis of the natural and waste raw materials, wt $\%$

\begin{tabular}{|c|c|c|c|c|c|c|c|}
\hline & $\mathrm{L}$ & $\mathrm{B}$ & $\mathrm{G}$ & $\mathrm{C}$ & $\mathrm{B} 1$ & B2 & B3 \\
\hline $\mathrm{CaO}$ & 55.16 & - & 30.10 & 10.40 & 49.92 & 27.13 & 16.84 \\
\hline $\mathrm{SiO}_{2}$ & - & 7.20 & 3.00 & 54.10 & 21.35 & 37.70 & 44.38 \\
\hline $\mathrm{Al}_{2} \mathrm{O}_{3}$ & - & 56.30 & 0.90 & 11.50 & 4.23 & 8.62 & 10.67 \\
\hline $\mathrm{Fe}_{2} \mathrm{O}_{3}$ & - & 6.30 & 0.30 & 4.50 & 3.86 & 10.54 & 11.63 \\
\hline $\mathrm{SO}_{3}$ & - & - & 36.20 & - & 7.26 & 6.87 & 5.51 \\
\hline Others & - & 2.30 & 3.70 & 6.40 & 1.89 & 3.28 & 2.97 \\
\hline L.o.i.* & 43.40 & 27.50 & 24.60 & 13.10 & 11.48 & 5.85 & 8.00 \\
\hline
\end{tabular}

\section{Mixtures Design and Cements Preparation}

Four BCSA clinker-generating raw mixtures were designed according to the modified Bogue equations [Irvin et al., 2011], assuming that $\mathrm{C}_{2} \mathrm{~S}, \mathrm{C}_{4} \mathrm{~A}_{3} \$, \mathrm{C}_{4} \mathrm{AF}$ and $\mathrm{C} \$$ amount fell in the range $45 \%-60 \%, 20 \%-30 \%, 8 \%-20 \%$ and $4 \%-10 \%$, respectively; moreover, a free $\mathrm{CaO}$ concentration value lower than $1.5 \%$ was also considered. All the mixtures contained L, B and G; a reference mix (MR) included also clay $(\mathrm{C})$, whereas the remaining three mixtures (M1, M2 and M3) alternately contained B1, B2 or B3 as total substitute for C. Table 3 and 4 respectively report the modified Bogue potential mineralogical composition of the four clinkers (CLIR, CLI1, CLI2 and CLI3) and the raw meals proportion.

Table 3. Bogue potential mineralogical composition of the clinkers, wt $\%$

\begin{tabular}{|c|c|c|c|c|}
$\mathrm{C}_{2} \mathrm{~S}$ & $\mathrm{C}_{4} \mathrm{~A}_{3} \$$ & $\mathrm{C}_{4} \mathrm{AF}$ & $\mathrm{C} \$$ & $\mathrm{C}$ \\
\hline
\end{tabular}




\begin{tabular}{|l|r|r|r|r|r|}
\hline CLIR & 56.0 & 25.9 & 8.3 & 5.1 & 0.1 \\
\hline CLI1 & 48.7 & 23.9 & 12.4 & 9.7 & 1.4 \\
\hline CLI2 & 52.6 & 20.7 & 17.9 & 4.9 & 0.1 \\
\hline CLI3 & 50.2 & 22.8 & 16.4 & 7.1 & 0.1 \\
\hline
\end{tabular}

The raw mixtures were heated in covered platinum crucibles in a laboratory electric oven for two hours at $1200^{\circ}, 1250^{\circ}, 1300^{\circ}$ and $1350^{\circ} \mathrm{C}$ and then rapidly cooled to room temperature; the obtained BCSA clinkers were finely ground in a Fritsch Pulverisette 6 (FP6) laboratory planetary mill to pass a $90 \mu \mathrm{m}$ sieve and afterwards submitted to XRD analysis in order to assess the best temperature for maximizing both $\mathrm{C}_{2} \mathrm{~S}$ and $\mathrm{C}_{4} \mathrm{~A}_{3} \$$ concentration.

Table 4. Composition of the raw meals, wt $\%$

\begin{tabular}{|l|c|c|c|c|c|c|c|}
\hline & L & B & G & C & B1 & B2 & B3 \\
\hline MR & 53.0 & 13.0 & 12.0 & 22.0 & - & - & - \\
\hline M1 & 50.0 & 13.0 & 5.0 & - & 56.0 & - & - \\
\hline M2 & 20.0 & 16.0 & 8.0 & - & - & 32.0 & - \\
\hline M3 & 52.0 & 13.5 & 10.0 & - & - & - & 24.5 \\
\hline
\end{tabular}

BCSA cements (CEMR, CEM1, CEM2 and CEM3) were then prepared by grinding the best obtained clinkers with G in the FP6 laboratory mill always to pass the $90 \mu \mathrm{m}$ sieve. The amount of the added gypsum was determined considering both the C\$ already present in the clinker (calculated with the modified Bogue equation) and the reaction stoichiometry for the generation of ettringite $\left(\mathrm{C}_{6} \mathrm{~A}_{3} \mathrm{H}_{32}\right.$, the main hydration product regulating the technical behavior at early ages) and aluminium hydroxide $\left(\mathrm{AH}_{3}\right)$ [Manzano et al., 2012; Telesca et al., 2014c], namely:

$\mathrm{C}_{4} \mathrm{~A}_{3} \$+2 \mathrm{C} \$+38 \mathrm{H} \Rightarrow \mathrm{C}_{6} \mathrm{~A} \$ \mathrm{H}_{32}+2 \mathrm{AH}_{3}$

XRD analysis was also employed for the evaluation of BCSA cements hydration products; it was performed with a Bruker D2 Phaser diffractometer $(\mathrm{CuK} \alpha$ radiation and $0.02^{\circ} 2 \theta \mathrm{s}^{-1}$ scanning rate).

\section{Measurements on Mortars}

BCSA mortar prisms were prepared according to the European Standard EN 196-1 and cured after demolding under water at $20^{\circ} \pm 1^{\circ} \mathrm{C}$; they were submitted to compressive strength measurements at curing periods ranging from 1 to 56 days.

\section{Measurements on Pastes}

BCSA cements were paste hydrated with a water/cement ratio equal to 0.5 by mass. The paste samples were cast into $15-\mathrm{mm}$-high and 30-mm-diameter cylindrical molds, and finally placed in polyethylene bags inside a thermostatic bath (at $20^{\circ} \mathrm{C}$ and $95 \%$ relative humidity) for curing times ranging from 4 hours to 56 days. At the end of each aging period the specimens were first crushed and then treated with acetone (to stop hydration) and diethyl ether (to remove water); the pulverized samples were subsequently stored in a desiccator over silica gel-soda lime (to ensure protection 
against $\mathrm{H}_{2} \mathrm{O}$ and $\mathrm{CO}_{2}$ ) and finally submitted to simultaneous DT-TG (NETZSCH-Tasc $414 / 3$ apparatus, heating rate $10^{\circ} \mathrm{C} \mathrm{min}^{-1}$, operating between room temperature and $1000^{\circ} \mathrm{C}$ ) and XRD analyses.

For the expansion-shrinkage measurements, eight paste samples, shaped as small prisms $(15 \times 15 \times 78 \mathrm{~mm})$, were first air cured at $20^{\circ} \mathrm{C}$ for 4 hours and then demolded. Later on, one set of samples was aged at $20^{\circ} \mathrm{C}$ under tap water, the other stored in a controlled humidity $(\mathrm{H})$ chamber at $70 \%$ R.H. and $20^{\circ} \mathrm{C}$. The length changes were determined as average values of four measurements with a caliper accurate to $\pm 1 \mu \mathrm{m}$; the reference length for them was that evaluated just after demolding [Telesca et al., 2014b; Valenti et al., 2012].

\section{RESULTS AND DISCUSSION}

The intensity of the main XRD peaks of $\mathrm{C}_{2} \mathrm{~S}$ and $\mathrm{C}_{4} \mathrm{~A}_{3} \$$ were taken as a conversion index of the BCSA clinker-generating raw mixes toward these products. The "external standard method" [Cullity et al., 2001] was used and, as a reference line, the same reflection from pure $\mathrm{C}_{2} \mathrm{~S}$ and $\mathrm{C}_{4} \mathrm{~A}_{3} \$$ preparations (generated by high-temperature synthesis of analytical grade calcium carbonate and quartz for the former and calcium carbonate, alumina and gypsum for the latter) was taken [Telesca et al., 2015]. The XRD intensity (cps) of the $\mathrm{C}_{2} \mathrm{~S}$ and $\mathrm{C}_{4} \mathrm{~A}_{3} \$$ lines is plotted as a function of the heating temperature (Figure 2 (a) and 2 (b), respectively); each curve displays a maximum occurring, for $\mathrm{C}_{2} \mathrm{~S}$, at about $1200{ }^{\circ} \mathrm{C}$ (MR and $\mathrm{M} 2$ ) or $1250^{\circ} \mathrm{C}$ (M1 and $\mathrm{M} 3$ ). Concerning calcium sulfoaluminate, the best synthesis temperature was the same as that of belite for mixtures $\mathrm{M} 1$ and $\mathrm{M} 2$, while higher for $\mathrm{MR}\left(1250^{\circ} \mathrm{C}\right)$ and $\mathrm{M} 3$ $\left(1300^{\circ} \mathrm{C}\right)$.
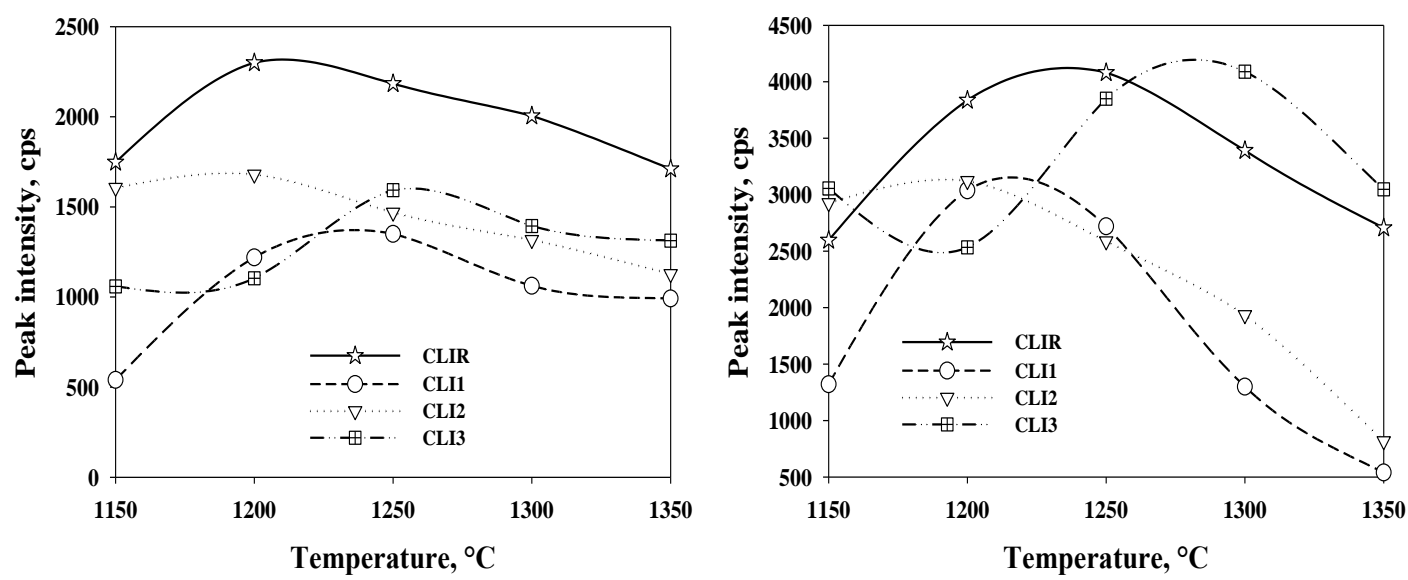

Figure 2. XRD intensity (counts per second, cps) of the $\mathrm{C}_{2} \mathrm{~S}$ and $\mathrm{C}_{4} \mathrm{~A}_{3} \$$ main peak for the BCSA clinkers as a function of the synthesis temperature.

From an overall examination of the XRD data about the synthetic BCSA clinkers it was found hat that, at every investigated temperature, the conversion of reactants was complete and $\mathrm{C}_{2} \mathrm{~S}$ and $\mathrm{C}_{4} \mathrm{~A}_{3} \$$ were the main burning products. Furthermore, $\mathrm{C}_{4} \mathrm{AF}$, $\mathrm{C}_{2} \mathrm{AS}$ and $\mathrm{C} \$$ frequently occurred as secondary components. 
Figure 3 illustrates the XRD patterns of mixtures MR, M1, M2 and M3 heated at the best synthesis temperatures. The four BCSA cements obtained from the synthetic clinkers generated by RM, M1, M2 and M3 at their best synthesis temperature were respectively denoted with the symbols CEMR, CEM1, CEM2 and CEM3.
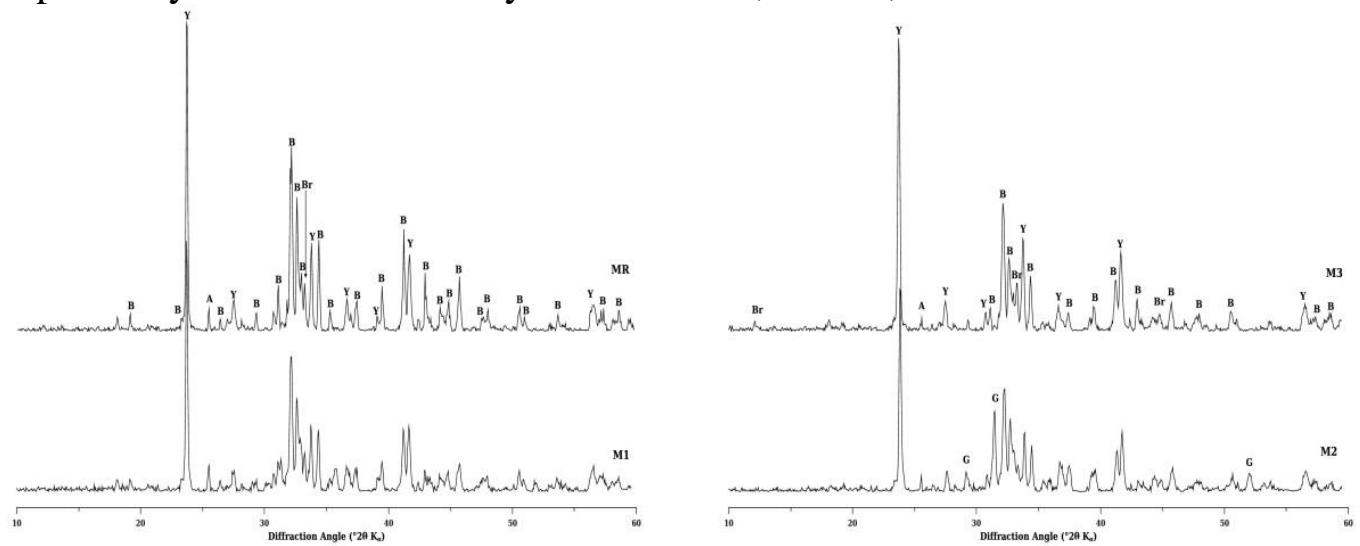

Figure 3. XRD patterns for the BCSA clinkers obtained from MR, M1, M2 and M3 at their best synthesis temperature. Legend to symbols: $Y=C_{4} A_{3} \$, A=C \$, B=C_{2} S$, $\mathrm{G}=\mathrm{C}_{2} \mathrm{AS}, \mathrm{Br}=\mathrm{C}_{4} \mathrm{AF}$.

Table 5 reports the compressive strength development of BCSA-based mortars as a function of curing time; at all the investigated periods, the compressive strength values of CEMR, CEM2 and CEM3 based-mortars were similar to each other; on the contrary, the compressive strength values of CEM1 were constantly lower than those of the other cements.

Table 5. Results of compressive strength measurements of CEMR, CEM1, CEM2 and CEM3 at various aging periods.

\begin{tabular}{|c|c|c|c|c|}
\hline Days & CEMR & CEM1 & CEM2 & CEM3 \\
\hline 1 & $12.7 \pm 0.4$ & $8.7 \pm 0.5$ & $10.9 \pm 0.3$ & $12.2 \pm 0.3$ \\
\hline 2 & $19.2 \pm 0.3$ & $14.5 \pm 0.2$ & $16.1 \pm 0.5$ & $19.7 \pm 0.2$ \\
\hline 7 & $26.4 \pm 0.2$ & $20.4 \pm 0.6$ & $24.5 \pm 0.5$ & $27.9 \pm 0.5$ \\
\hline 14 & $32.5 \pm 0.1$ & $24.6 \pm 0.3$ & $30.5 \pm 0.8$ & $33.5 \pm 0.2$ \\
\hline 28 & $37.1 \pm 0.5$ & $26.9 \pm 0.1$ & $34.5 \pm 0.7$ & $36.8 \pm 0.4$ \\
\hline 56 & $36.9 \pm 0.7$ & $28.4 \pm 0.5$ & $35.1 \pm 0.8$ & $37.1 \pm 0.3$ \\
\hline
\end{tabular}

The compressive strength results refer to three prisms (six determinations)

The results of the expansion-shrinkage tests are illustrated in Figure 4. 


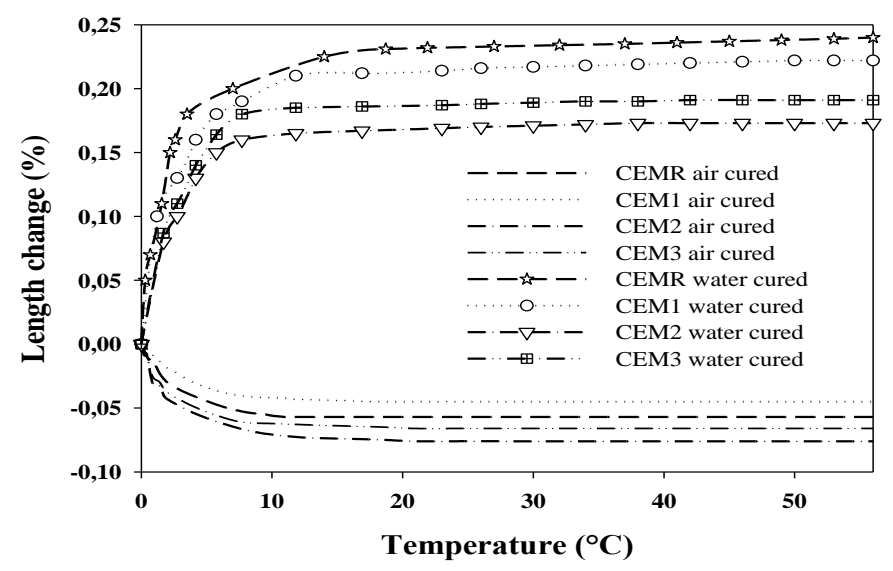

Figure 4: Dimensional stability curves for BCSA-based cements (air and water cured). They indicate that all the investigated BCSA cements differed very little from each other, both when submerged under water and cured in air. In particular, under water the maximum expansion values, reached after about 14 days of curing, are comprised in the narrow range of $0.17-0.23 \%$. When cured in air, the investigated pastes showed a continuous shrinkage till 14 days when a minimum length change is reached $(-0.06 \%$, $-0.05 \%,-0,08$ and $-0.07 \%$ for CEMR, CEM1, CEM 2 and CEM3, respectively); since that period the values remained constant for all the investigated systems.

The change of mineralogical phases with ongoing hydration was determined through XRD and DT-TG investigations. The XRD analysis of all the BCSA cements revealed, as expected, that after 4 hours of hydration ettringite had already formed at the expense of part of calcium sulfoaluminate and calcium sulfates. At 28 days of curing ettringite was still the main crystalline phase of hydrated cements which also revealed the presence of some traces of $\mathrm{C}_{4} \mathrm{~A}_{3} \$$ and inert phases (e.g. gehlenite). At the same curing period, strätlingite $\left(\mathrm{C}_{2} \mathrm{ASH}_{8}\right)$, which started forming already after 1 day of curing in CEMR and CEM1, was evident together with katoite $\left(\mathrm{C}_{3} \mathrm{AH}_{6}\right)$ in all the investigated systems. These compounds had respectively formed from belite (as silicon source) and $\mathrm{AH}_{3}$ (as aluminium source) and from the remaining belite and $\mathrm{C}_{2} \mathrm{ASH}_{8}$ according to the following equations [Winnefeld et al., 2016]:

$$
\begin{aligned}
& \mathrm{C}_{2} \mathrm{~S}+\mathrm{AH}_{3}+5 \mathrm{H} \Rightarrow \mathrm{C}_{2} \mathrm{ASH}_{8} \\
& \mathrm{C}_{2} \mathrm{~S}+\mathrm{C}_{2} \mathrm{ASH}_{8} \Rightarrow \mathrm{CSH}_{2}+\mathrm{C}_{3} \mathrm{AH}_{6}
\end{aligned}
$$

Moreover, $\mathrm{AH}_{3}$ was not detected at any curing period due to its amorphous nature. No significant changes were observed at 56 days of curing in the four hydrated systems. As an example, XRD patterns for CEMR, CEM1 and CEM3 hydrated at 4 hours, 1 and 56 days are reported in Figure 5. 

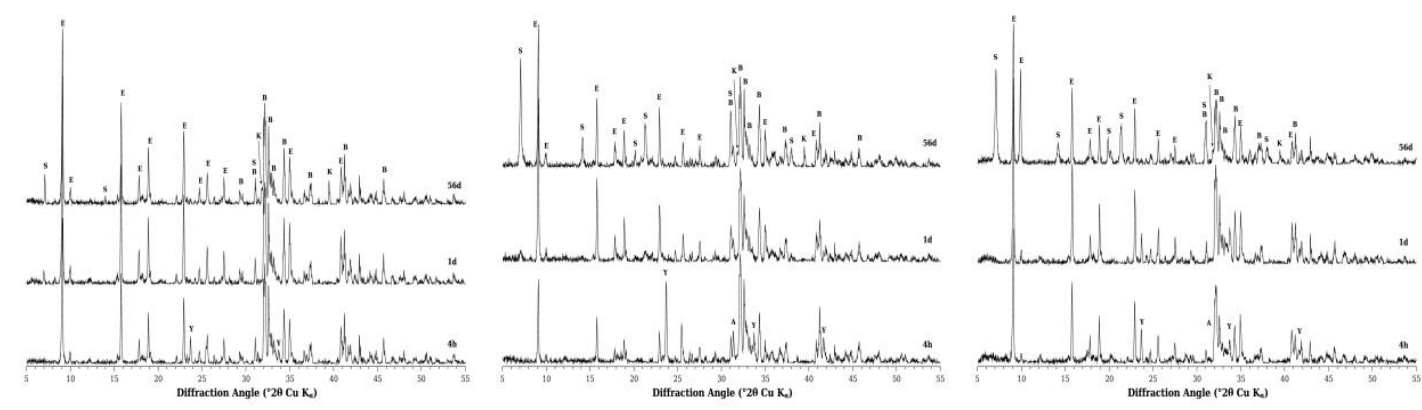

Figure 5. XRD patterns for CEMR (left), CEM1 (middle) and CEM3 (right) hydrated for 4 hours, 1 and 56 days. Legend to symbols: $\mathrm{E}=\mathrm{C}_{6} \mathrm{~A} \$ \$_{3} \mathrm{H}_{32}, \mathrm{Y}=\mathrm{C}_{4} \mathrm{~A}_{3} \$, \mathrm{~S}=\mathrm{C}_{2} \mathrm{ASH}_{8}$, $\mathrm{K}=\mathrm{C}_{3} \mathrm{AH}_{6}, \mathrm{~B}=\mathrm{C}_{2} \mathrm{~S}$.

The DT-TG analyses almost confirmed the mineralogical evaluations made by XRD. Three endothermal effects were observed and attributed, on the basis of literature data [Taylor, 1997], to the following compounds: ettringite (E) and, contrary to XRD data, calcium silicate hydrate $(\mathrm{CSH})$ and aluminum hydroxide $\left(\mathrm{AH}_{3}\right)$; in particular, $\mathrm{CSH}, \mathrm{E}$ and $\mathrm{AH}_{3}$ were respectively detected through the following dehydration endothermal peaks: $103^{\circ} \pm 4^{\circ} \mathrm{C}, 152^{\circ} \pm 5^{\circ} \mathrm{C}, 277^{\circ} \pm 3^{\circ} \mathrm{C}$. Strätlingite could not be identified inasmuch as its DT peak was overlapped by the et

(a)
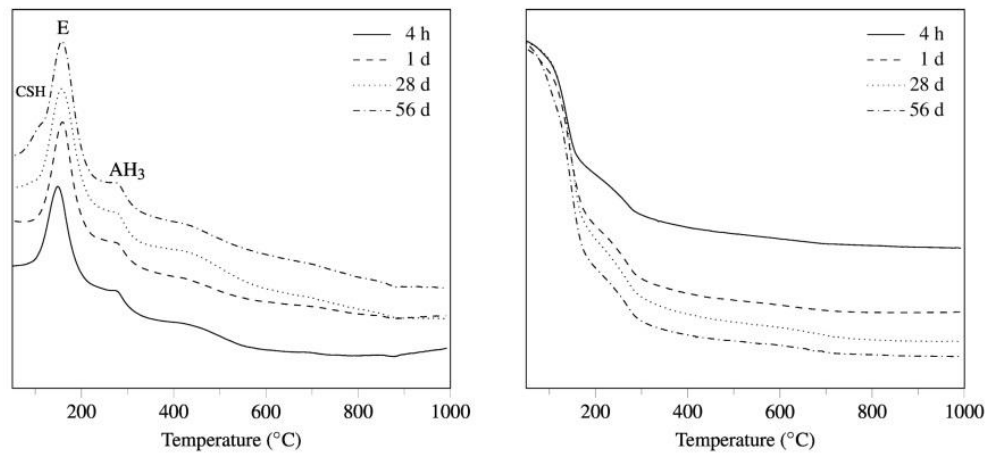

(b)
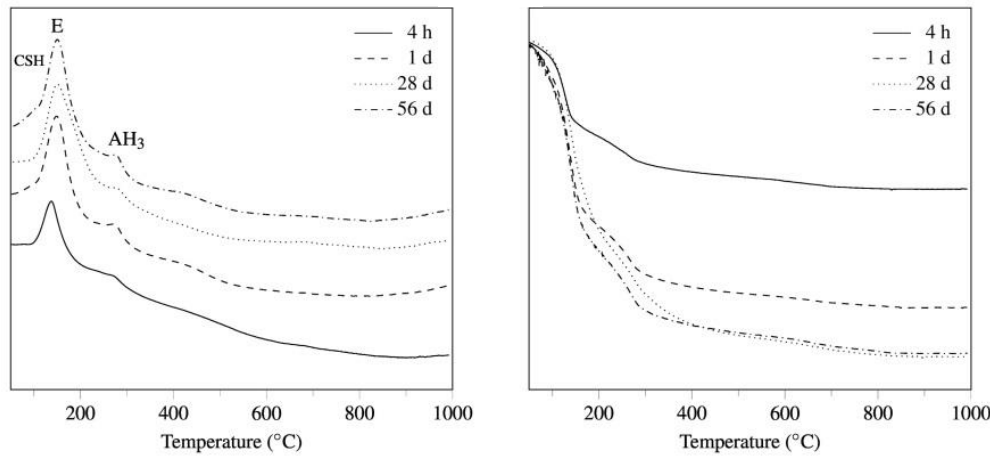
(c)
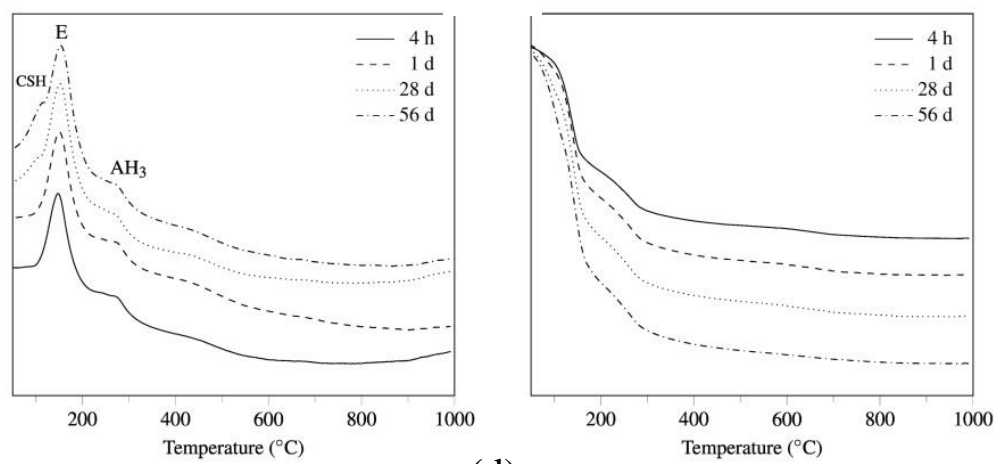

(d)
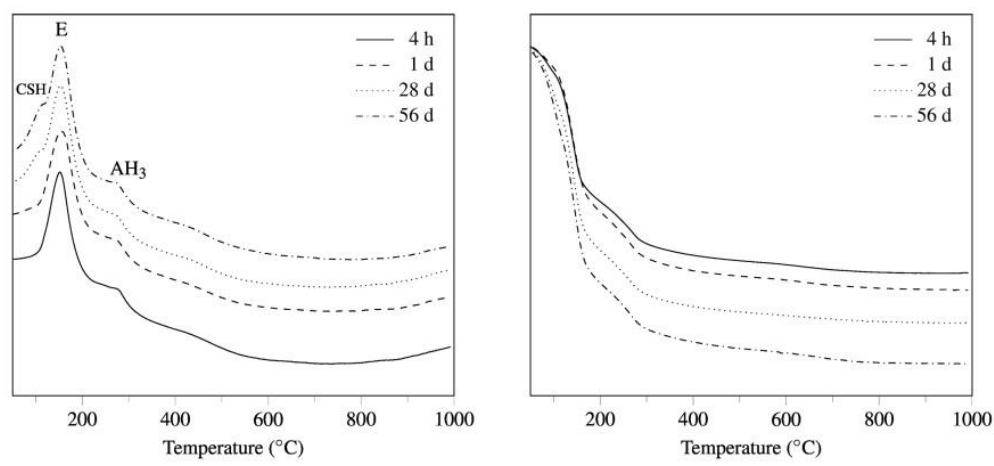

Figure 6: DT-TG thermograms for BCSAR (a), BCSA1 (b), BCSA2 (c) and BCSA3 (d), hydrated for 4 hours, 1, 28 and 56 days. Legend to symbols: $\mathrm{CSH}=$ calcium silicate hydrate; E=ettringite; $\mathrm{AH}=$ aluminium hydroxide.

$\mathrm{CSH}$ originated from the reaction between belite and strätlingite according to reaction (3); ettringite and aluminum hydroxide represented the main reaction products of $\mathrm{C}_{4} \mathrm{~A}_{3} \$$ hydration (equation 1). From the examination of the DT-TG results (Figure 6), it can be drawn that: (a) the thermograms for all the BCSA cements are qualitatively similar; (b) the peak intensities for $\mathrm{E}$ and $\mathrm{AH}_{3}$ generally increase with the increase in the curing time; (c) the presence of CSH is evident starting from 28 days of curing for CEMR, CEM2 and CEM3, only from 56 days for CEM1.

\section{CONCLUSIONS}

The OC residues, generated in an oxyfuel combustion plant, represent a suitable substitute for clay as a silico-aluminous source in belite calcium sulfoaluminate (BCSA) clinker-generating raw mixes. Therefore, the well-recognized environmentally friendly character of the BCSA cement manufacture can be further improved by using industrial wastes and by-products instead of natural materials. It has been found that three different waste-based mixes, laboratory heated at $1200^{\circ}$ or $1250^{\circ} \mathrm{C}$ were able to give, like the reference mix containing only natural materials, high conversion of reactants and good selectivity toward the main BCSA cement components $\left(\mathrm{C}_{2} \mathrm{~S}\right.$ and $\left.\mathrm{C}_{4} \mathrm{~A}_{3} \$\right)$. The XRD and DT-TG analyses carried out for investigating the hydration behaviour of the BCSA cements, demonstrated that no significant differences associated with the kind of the clayish source were found. 
Because of the strong dependence of the cement technical performance on its hydration characteristics, it can be argued that the similarity in the hydraulic behavior among the investigated cements most likely results in analogous engineering properties; this was confirmed by the expansion/shrinkage measurements as well as mechanical compressive strength results.

\section{REFERENCES}

Activity Report 2016 (2017), The European Cement Association, (http://www. cembureau.be/).

Barcelo, L., Kline, J., Walenta, G., and Gartner, E. (2014). "Cement and carbon emissions." Mater. Struct., 47, 1055-1065.

Benhelal, E., Zahedi, G., Shamsaei, E., and Bahadori, A. (2013). "Global strategies and potentials to curb $\mathrm{CO}_{2}$ emissions in cement industry". J. Clean. Prod., 51, $142-161$.

Boot-Handford, M.E., Abanades, J.C., Anthony, E.J., Blunt, M.J., Brandani, S., Mac Dowell, N., Fernández, J.R., Ferrari, M.C., Gross, R., Hallett, J.P., Haszeldine, R.S., Heptonstall, P., Lyngfelt, A., Makuch, Z., Mangano, E., Porter, R.T.J., Pourkashanian, M., Rochelle, G.T., Shah, N., Yao, J.G., Fennell, P.S. (2014). "Carbon capture and storage update". En. Environ. Sci., 7, 130-189.

Buhre, B.J.P., Elliott, L.K., Sheng, C.D., Gupta, R.P., and Wall, T.F. (2005). "Oxyfuel combustion technology for coal-fired power generation." Progr. in En. and Comb. Sci., 31, 283-307.

Cuberos, A.J.M., De La Torre, A.G., Martin-Sedeno, M.C., Schollbach, K., Pollmann, H., and Aranda, M.A.G. (2010). "Active iron-rich belite sulfoaluminate cements: Clinkering and hydration." Environ. Sci. Technol., 44, 6855-6862.

Cullity, B. D., and Stock, S. R. (2001). “Elements of X-ray Diffraction.” Prentice Hall: Upper Saddle River, NJ.

DeRichter, R.K., Ming, T., Caillol, S., and Liu, W. (2016). "Fighting global warming by GHG removal: destroying CFCs and HCFCs in solar-wind power plant hybrids producing renewable energy with no-intermittency". Int. J. Greenh. Gas Contr., 49, 449-472.

Díez, L.I., Lupiáñez, C., Guedea, I., Bolea, I., and Romeo, L.M. (2015). "Anthracite oxy-combustion characteristics in a $90 \mathrm{~kW}_{\text {th }}$ fluidized bed reactor." Fuel Proc. Tech. 139, 196-203.

Irvin, A.C., and Juenger, M.C.G. (2011). "Synthesis and hydration of calcium sulfoaluminate-belite cementswith varied phase compositions." J-Mater. Sci., 46, 2568-2577.

Leung, D.Y.C., Caramanna, G., and Maroto-Valer, M.M. (2014). "An overview of current status of carbon dioxide capture and storage technologies". Renew. Sust. Energ. Rev., 39 426-443.

Lupiáñez, C., Díez, L.I., and Romeo, L.M. (2013a). "NO emissions from anthracite oxy-firing in a fluidized-bed combustor: effect of the temperature, limestone, and $\mathrm{O}_{2} . "$ Energy \& Fuels, 27, 7619-7627. 
Lupiáñez, C., Guedea, I., Bolea, I., Díez, L.I., and Romeo, L.M. (2013b). "Experimental study of $\mathrm{SO}_{2}$ and $\mathrm{NO}_{\mathrm{x}}$ emissions in fluidized bed oxy-fuel combustion." Fuel Process. Technol., 106, 587-594

Lupiáñez, C., Díez, L.I., and Romeo, L.M. (2014). "Influence of gas-staging on pollutant emissions from fluidized bed oxy-firing." Chemical Engineering Journal, 256, 380-389.

Ma, B., Li, X., Shen, X., Mao, Y., Huang, H. (2014). "Enhancing the addition of fly ash from thermal power plants in activated high belite sulfoaluminate cement." Constr. Build. Mat, 52, 261-266.

Manzano, H., Ayuela, A., Telesca, A., Monteiro, P. J. M., and Dolado, J. S. (2014). "Ettringite strengthening at high pressures induced by the densification of the hydrogen bond network." J. Phys. Chem. C, 116, 16138-16143.

Marroccoli, M., Montagnaro, F., Pace, M.L., Telesca, A., and Valenti, G.L. (2009) "Use of fluidized bed combustion ash and other industrial wastes as raw materials for the manufacture of calcium sulphoaluminate cements". Proc. $20^{\text {th }}$ Int. Conf. Fluid. Bed Comb., 1072-1077.

Marroccoli, M., Montagnaro, F., Telesca, A., and Valenti, G.L. (2010a). "Environmental implications of the manufacture of calcium sulfoaluminatebased cements." Proc. $2^{\text {nd }}$ Int. Conf. Sust. Constr. Mat. and Techn., paper n.162.

Marroccoli, M., Pace, M.L., Telesca, A., and Valenti, G.L. (2010b) "Synthesis of Calcium sulfoaluminate cements from $\mathrm{Al}_{2} \mathrm{O}_{3}$-rich by-products from Aluminium Manufacture." Proc. $2^{\text {nd }}$ Int. Conf. Sust. Constr. Mat. and Techn., paper n.161.

Pimraksa, K., Hanjitsuwan, S., Chindaprasirt, P. (2009). "Synthesis of belite cement from lignite fly ash." Ceram. Int., 35, 2415-2425.

Quillin, K. (2001). "Performance of belite-sulfoaluminate cements." Cem. Concr. Res., 31, 1341-1349.

Romeo, L.M., Díez, L.I., Guedea, I., Bolea, I., Lupiáñez, C., González, A., Pallarés, J., and Teruel, E. (2011). "Design and operation assessment of an oxyfuel fluidized bed combustor." Exp. Thermal Fluid Sci., 35, 477-484.

Selçuk, N., Soner, I., and Selçuk, E. (2010) "Synthesis of special cement with fluidised bed combustion ashes." Adv. Cem. Res., 22, 107-113.

Shen, Y., Qian, J. (2015). "Utilisation of phosphogypsum for sulfate-rich belite sulfoaluminate cement production.” Adv. Cem. Res., 27, 515-525.

Szulejko, J.E., Kumar, P., Deep, A., and Kim, K. (2017). “Global warming projections to 2100 using simple $\mathrm{CO}_{2}$ greenhouse gas modeling and comments on $\mathrm{CO}_{2}$ climate sensitivity factor". Atm. Poll. Res., 8, 136-140

Taylor, H.F.W. (1997). Cement chemistry. $2^{\text {nd }}$ Ed. (London), Thomas Telford.

Telesca, A., Calabrese, D., Marroccoli, M., Tomasulo, M., Valenti, G.L., Duelli (Varela), G., and Montagnaro, F. (2014a). "Spent limestone sorbent from calcium looping cycle as a raw material for the cement industry." Fuel, 118, 202-205.

Telesca, A., Marroccoli, M., Pace, M.L., Tomasulo, M., Valenti, G.L., and Monteiro, P.J.M. (2014b). "A hydration study of various calcium sulfoaluminate cements". Cem. Concr. Comp., 53, 224-232.

Telesca, A., Calabrese, D., Marroccoli, M., Valenti, G.L., and Montagnaro, F. (2014c) "Study of the hydrothermal treatments of residues from fluidized bed 
combustors for the manufacture of ettringite-based building elements". Fuel Proc. Tech., 126, 188-191.

Telesca, A., Marroccoli, M., Tomasulo, M., Valenti, G.L., Dieter, H., and Montagnaro, F. (2015). "Calcium looping spent sorbent as a limestone replacement in the manufacture of Portland and calcium sulfoaluminate cements." Environ. Sci. Technol., 49, 6865-6871.

Telesca, A., Marroccoli, M., Tomasulo, M., Valenti, G.L., Dieter, H., and Montagnaro, F. (2016). "Low- $\mathrm{CO}_{2}$ Cements from Fluidized Bed Process Wastes and Other Industrial By-Products". Comb. Sci. Tech., 188 (4-5), 492-503.

Telesca, A., Marroccoli, M., Ibris, N., Lupiáñez, C., Díez, L.I., Romeo, L.M., and Montagnaro, F. (2017). "Use of oxyfuel combustion ash for the production of blended cements: a synergetic solution toward reduction of $\mathrm{CO}_{2}$ emissions". Fuel Proc. Tech. 156, 211-220.

Tregambi, C., Solimene, R., Montagnaro, F., Salatino, P., Marroccoli, M., Ibrid, N., and Telesca, A. (2018). "Solar-driven production of lime for ordinary Portland cement formulation." Solar En., 173, 759-768.

Valenti, G.L., Marroccoli, M., Pace, M.L., and Telesca, A. (2012). "Discussion of the paper "Understanding expansion in calcium sulfoaluminate-belite cements" by I.A. Chen et al." Cem. Concr. Res., 42, 1555-1559.

Winnefeld, F., and Lothenbach, B. (2016). "Phase equilibria in the system $\mathrm{Ca}_{4} \mathrm{Al}_{6} \mathrm{O}_{12} \mathrm{SO}_{4-}$ $\mathrm{Ca}_{2} \mathrm{SiO}_{4}-\mathrm{CaSO}_{4}-\mathrm{H}_{2} \mathrm{O}$ referring to the hydration of calcium sulfoaluminate cements." RILEM Tech. Lett., 1, 10-16.

Xue, P., Xu, A., He, D., Yang, Q., Liu, G., Engström, and Björkman, B. (2016). "Research on the sintering process and characteristics of belite sulphoaluminate cement produced by BOF slag." Constr. Build. Mat., 122, 567-576. 